\title{
ASPECTS OF TAX EDUCATION LEVEL OF UNIVERSITY STUDENTS
}

\author{
[Aspekty úrovně daňové vzdělanosti vysokoškolských studentů] \\ Šárka Sobotovičová ${ }^{1}$, Beáta Blechová $^{2}$ \\ ${ }^{I}$ Slezská univerzita, Obchodně podnikatelská fakulta, Univerzitní nám. 1934/3, 73340 Karviná \\ Email:sobotovicova@opf.slu.cz \\ ${ }^{2}$ Slezská univerzita, Obchodně podnikatelská fakulta, Univerzitní nám. 1934/3, 73340 Karviná \\ Email:blechova@opf.slu.cz.
}

\begin{abstract}
The article deals with the research of tax literacy of university students on the School of Business Administration in Karvina. Tax legislation significantly affects the business and social environment in the Czech Republic. Hence the School of Business Administration in Karvina provides its students with key information on field of taxation and fiscal policy. Specificity of teaching taxes and tax policy consists in linking academic education with vocational qualification. The aim of the research is to identify and verify the extent to which teaching subjects, dealing with tax issues, affects the level of students' knowledge in connection with a chosen type of studies. The research focuses on the tax knowledge of students from Bachelor and Follow-up Masters degree programmes, both fulltime and part-time forms of studies. The questionnaire is aimed at verifying the basic tax literacy of students. To determine whether there is a significant difference in students' knowledge the chi-square test has been used.
\end{abstract}

Keywords: consumption taxes, education, income taxes, knowledge, tax literacy.

JEL classification: A23, H2

Doručeno redakci: 14.10.2015; Recenzováno: 16.10.2015; 27.10.2015; Schváleno k publikování: 15.12.2015

\section{Úvod}

V současnosti se stále zvyšuje význam vzdělávání v souvislosti s poskytováním odborných dovedností. Jedná se o jednu z oblastí, které se výrazně podílí na budoucím uplatňování absolventů vysokých škol na trhu práce. Potřeba kvalitních znalostí a důvěryhodných informací z oblasti ekonomiky, financí a daní na jejichž podkladě bude moci každý činit správná rozhodnutí př̀ správě osobních, rodinných a podnikových financí roste v souvislosti se zařazením České republiky mezi moderní tržní ekonomiky. Rozvoj finančních služeb, ale zejména také ekonomická krize upozornila na nezbytnost finančního vzdělávání, jehož nedílnou součástí je i daňová problematika, které je věnována značná pozornost ze strany podnikatelů, veřejně správních institucí i státu.

Na Obchodně podnikatelské fakultě v Karviné Slezské univerzity v Opavě je katedrou financí a účetnictví garantováno celkem devět předmětů s daňovou problematikou, a to Daně a daňová politika ČR, Daně a daňová politika $\mathrm{A}$, Daně a daňová politika $\mathrm{B}$, Daně a daňová politika Evropské unie, Účetní a daňové praktikum, Aplikace daňového práva, Daňová evidence podnikatele, Zdanění spotřeby a Zdanění majetku a spotřeby.

V rámci studia jsou studenti postupně seznamování s klíčovými informacemi z oblasti daní přímých i nepřímých, daňové politiky státu, včetně konkrétních daní daňové soustavy ČR, ale i s daňovými souvislostmi zapojení ČR do mezinárodních hospodárských struktur a s harmonizací právních norem ČR s normami EU vymezujícími problematiku daní. 


\section{Teoretické a empirické př́stupy k finanční a daňové gramotnosti}

Dle Kollárikové (2014) je lidský kapitál formou kapitálu, který vlastní lidé tím, že disponují určitým souborem schopností, dovedností, znalostí a moudrostí. V podmínkách dnešní znalostní společnosti jde o klíčový faktor $\mathrm{k}$ dosahování konkurenceschopnosti a rozvoje ekonomik. Vzdělávání je proto nesmírně důležitou součástí celého procesu rozvoje lidského kapitálu. Podle Tokarčíkové, Kucharčíkové a Ďurišové (2015) hrají vysoké školy jako centra znalostí důležitou úlohu ve vzdělávání. Nejsou pouze institucemi vyššího vzdělání, udělujícími vědecké tituly, ale společně vychovávají zodpovědné lidi s odbornými znalostmi, kteří jsou následně schopni tyto znalosti využít při řešení problémů.

Problematice významu úrovně vysokých škol a vlivu kvalitního odborného vzdělání na konkurenceschopnost a zaměstnanost kvalifikovaných pracovníků se věnují rovněž Boccanfuso, Larouche a Trandafir (2015), kteří úroveň vzdělání považují za klíčovou otázku ekonomického a sociálního rozvoje. Kompetence, efektivnost a užitečné vědomosti a dovednosti jsou základem nové ekonomiky. Jak uvádí Kucharčíková (2014), firmy a společnosti potřebují vysoce kvalifikované pracovníky.

Finanční gramotnost se stává stále důležitějším hlediskem také pro vládní, vzdělávací a společenskovědní obory, nejenom pro oblast finančních institucí a poradců (Chardon 2014). V souladu s růstem významu se tato oblast stala předmětem zájmu, výzkumů a studií mnoha autorů na celém světě. Problematikou vlivu nízké úrovně finanční gramotnosti na finance domácností v kontextu čerpání spotřebitelských úvěrů konečnými spotřebiteli se zabývají Disney a Gathergood (2013).

Yilmaz (2011) tvrdí, že finanční vzdělávání je důležitou součástí každodenního života lidí a finanční gramotnost představuje významné téma $\mathrm{v}$ rámci celosvětových hospodářských a finančních zájmů. Zlepšení finanční gramotnosti je možno dosáhnout prostřednictvím finančního vzdělávání. Samotný princip finančního vzdělávání a gramotnosti, navíc naráží na skutečnost, že různé finanční nástroje jsou př́liš komplikované, některé z nich nejsou přesně a pochopeny ani lidmi, kteří jsou obecně považováni za odborníky v oboru (Paseková et al., 2013). Problematikou zvyšování finanční a daňové gramotnosti v kontextu výuky na vysokých školách se zabývají ve své studii rovněž např. Gillen a Loeffler (2012).

V České republice bylo $\mathrm{v}$ roce 2005 vydáno usnesení vlády, jímž byl stanoven úkol vybudování systému finančního vzdělávání na základních a středních školách. Finanční gramotnost byla v České republice definována v roce 2006, v rámci činnosti mezirezortní Pracovní skupiny pro finanční vzdělávání jako soubor znalostí a dovedností, které člověku umožňují porozumět financím a správně $\mathrm{s}$ nimi zacházet $\mathrm{v}$ různých životních situacích. V Evropské unii byla na základě Rozhodnutí komise ze dne 30. 4. 2008 zř́zena skupina odborníků pro finanční vzdělávání (Commission decision 2008/365/EC) avšak systémy finančního vzdělávání se $\mathrm{v}$ jednotlivých státech EU velmi liší. V roce 2003 vytvořila OECD Projekt finančního vzdělávání. Národní strategie finančního vzdělávání existuje také v USA, a to již od roku 2003.

Nedílnou a významnou součástí finanční gramotnosti je i daňová oblast včetně makroekonomických aspektů, a to zejména vzhledem $\mathrm{k}$ tomu, že se významně podílí na finančních zdrojích jednotlivců i domácností, a má tedy významný vliv na peněžní toky v soukromých financích. 
Finančně a daňově gramotný občan se orientuje $v$ problematice peněz a cen a je schopen odpovědně spravovat osobní/rodinný rozpočet, včetně správy finančních aktiv a finančních závazků s ohledem na měnící se životní situace (Janoušková 2011). Vzdělávací aktivity ve finanční a daňové oblasti rovněž mohou pomoci rozvíjet potřebné znalosti pro podnikání a obchodní dovednosti každého jednotlivce (Hadi et al., 2015).

Finanční gramotnost jako správa osobních či rodinných financí zahrnuje tři složky:

- peněžní gramotnost,

- cenovou gramotnost,

- rozpočtovou gramotnost (Vybíhal 2011)

Základní povědomí o daňovém systému a roli daní v rámci občanské společnosti je nutné chápat jako prvek k zajištění zodpovědného chování občanů vůči rodině a státu (Janoušková a Sobotovičová 2013). Csongor (2011) uvádí, že v životě je možno rozpoznat předvídatelné i nepředvídatelné situace a finančně gramotný člověk je schopen odhadnout míru možného finančního rizika a činit správná rozhodnutí.

Daně jsou problematikou, se kterou se denně setkává každý občan, jelikož nepřímé daně jsou součástí ceny pro konečného spotřebitele a důchodové daně se týkají jak občanů v zaměstnaneckém poměru tak i podnikatelů. Základní povědomí o daňovém systému a roli daní $\mathrm{v}$ rámci občanské společnosti je nutno chápat jako prvek $\mathrm{k}$ zajištění odpovědného chování občanů vůči rodině a státu (Blechová a Sobotovičová, 2013). Každý občan by měl mít základní znalosti o daňovém systému a daních, které jsou vybírány na území státu, ve kterém žije.

Problematikou posouzení úrovně daňové gramotnosti zaměstnanců v Malajsii se zabývali Kamaluddin a Madi (2005) a Madi et al. (2010). Zkoumali daňovou gramotnost zaměstnanců v závislosti na odvětví, ve kterém pracují. Daňová vzdělanost umožňuje orientovat se v daňovém systému. Eriksen a Fallan (1996) věřili, že s přiměřenou mírou pochopení daňových zákonů, jsou lidé ochotni respektovat daňový systém a jsou proto více ochotni daň platit namísto toho, aby se vyhýbali plnění daňových povinností.

Velkým problémem se však jeví velmi častá novelizace daňové legislativy, která způsobuje nepřehlednost a složitost daňového systému v rozporu se zásadou, že daně by měly být jasné a jednoduché (Blechová 2012). Změny daňových zákonů, ke kterým dochází nezř́ídka i několikrát ročně způsobují, že dosažení a hlavně udržení základní daňové gramotnosti je téměř nemožné.

Daňová legislativa významnou měrou ovlivňuje podnikatelské i společenské prostředí v České republice. Proto je záměrem Obchodně podnikatelské fakulty v Karviné poskytnout studentům $\mathrm{v}$ rámci výuky klíčové informace $\mathrm{z}$ oblasti daní a daňové politiky státu. Důraz je kladen na teoretické znalosti a na praktickou aplikaci získaných vědomostí, včetně prohloubení znalostí v oblasti př́mých i nepř́mých daní. Jednou ze základních specifik výuky této oblasti jsou zejména časté změny daňové legislativy a př́stupu státu k daňové politice

\section{Empirický výzkum a použité metody}

Cílem výzkumu bylo ověření daňových znalostí studentů a zhodnocení rozdílu ve znalostech studentů v závislosti na formě studia. V první části bylo zjišstováno, jaká je úroveň daňových znalostí, se kterými studenti na vysokou školu přicházejí. Druhá část výzkumu spočívala 
v ověření, jak se tyto znalosti zvýší po absolvování předmětů s daňovou problematikou, které jsou na Obchodně podnikatelské fakultě v Karviné Slezské univerzity v Opavě vyučovány.

\subsection{Použité metody}

Pro zjištění, zda existuje významný rozdíl ve znalostech studentů, byl použit chí-kvadrát test. Byla vytvořena kontingenční tabulka na základě pozorovaných četností a očekávaných četností, které byly dopočteny podle vzorce (1):

$$
E_{i j}=\frac{n_{i}}{n} \cdot \frac{n_{j}}{n} \cdot n=\frac{n_{i} n_{j}}{n}
$$

kde: $n_{i}$.je počet řádků,

$n_{. j}$ je počet sloupců kontingenčni tabulky,

n je celkový rozsah náhodného výběru.

Testové kritérium bylo vypočteno podle vzorce (2):

$$
T=\sum_{i=1}^{2} \sum_{j=1}^{s} \frac{\left(O_{i j}-E_{i j}\right)^{2}}{E_{i j}}
$$

kde: s znamená počet kategorií sledovaného znaku, tj. počet sloupců kontingenční tabulky, $O_{i j}$ predstavuje pozorované četnosti.

Kritická hodnota $K=\chi_{\alpha}(s-1)$ rozdělení Chi-kvadrát se stupněm volnosti $d f=s-1$ a pro zadanou hladinu významnosti $\alpha 0,05$ byla vypočtena pomocí Excelu použitím funkce $\operatorname{CHIINV}(\alpha ; d f)$.

Pro ověření správnosti byla vypočtena signifikace ( $p$-hodnota), která byla porovnána se zvolenou hladinou významnosti $(\alpha=0,05)$. Pro výpočet $p$-hodnoty byla využita funkce $\operatorname{CHIDIST}(T ; d f)$.

Vážený aritmetický průměr byl vypočten podle vzorce (3):

$$
\bar{x}_{w}=\frac{1}{\sum_{i=1}^{n} w_{i}} \sum_{i=1}^{n} w_{i} x_{i},
$$

kde: $w_{i}$ jsou váhy,

n je počet hodnot znaku.

Výběrový rozptyl byl vypočten podle vzorce (4):

$$
s^{2}=\frac{1}{n-1} \sum_{i=1}^{n}\left(x_{i}-\bar{x}\right)^{2}=\frac{\sum_{i=1}^{n} x_{i}^{2}-n \bar{x}^{2}}{n-1}
$$

kde: $n$-1 je počet stup̌̌ů volnosti.

\subsection{Dotazníkové šetření}

Dotazník je zaměřen na ověření základní daňové gramotnosti studenti̊. V dotazníku jsou využity otázky uzavřené výběrové. Otázky z oblasti zdanění př́ijmů fyzických osob ze závislé 
činnosti se týkají sazby daně, nezdanitelných částek a slev na dani. Z oblasti zdanění spotřeby jsou otázky zaměřeny pouze na obecnou znalost vybraných výrobků a sazeb daně.

Výzkum je zaměřen na zkoumání daňových znalostí u studentů v prezenční i kombinované formě. Návratnost dotazníků byla $100 \%$, jelikož byly respondentům osobně předány. V první části výzkumu byli osloveni respondenti, kteří nastoupili ke studiu, celkem bylo vyplněno 357 dotazníků prezenčními studenty a 163 dotazníků kombinovanými studenty. Další část výzkumu byla zaměřena na studenty, kteří absolvovali předměty $\mathrm{s}$ daňovou problematikou. Bylo osloveno 342 respondentů v prezenčním studiu a 148 studentů v kombinované formě studia.

Obrázek 1: Četnost správných odpovědí studentů v první fázi výzkumu

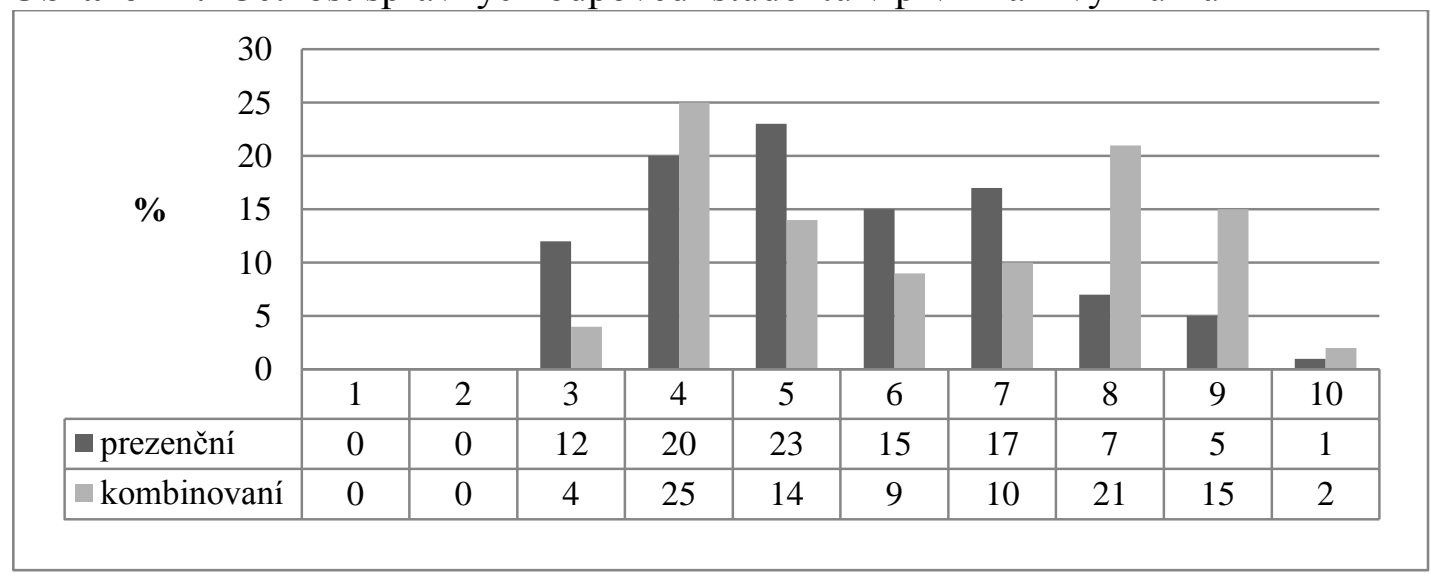

Zdroj: vlastní zpracování

Z výše uvedeného grafu je vidět, že modus pro prezenční studenty je 5 a pro kombinované pouze 4. Na druhou stranu však vážený aritmetický průměr (jak je zřejmé z tabulky 1) ukazuje lepší výsledky kombinovaných studentů, a to 6 správných odpovědí (u prezenčních studentů to bylo pouze 5 správných odpovědí).

Obrázek 2: Četnost správných odpovědí studentů ve druhé fázi výzkumu

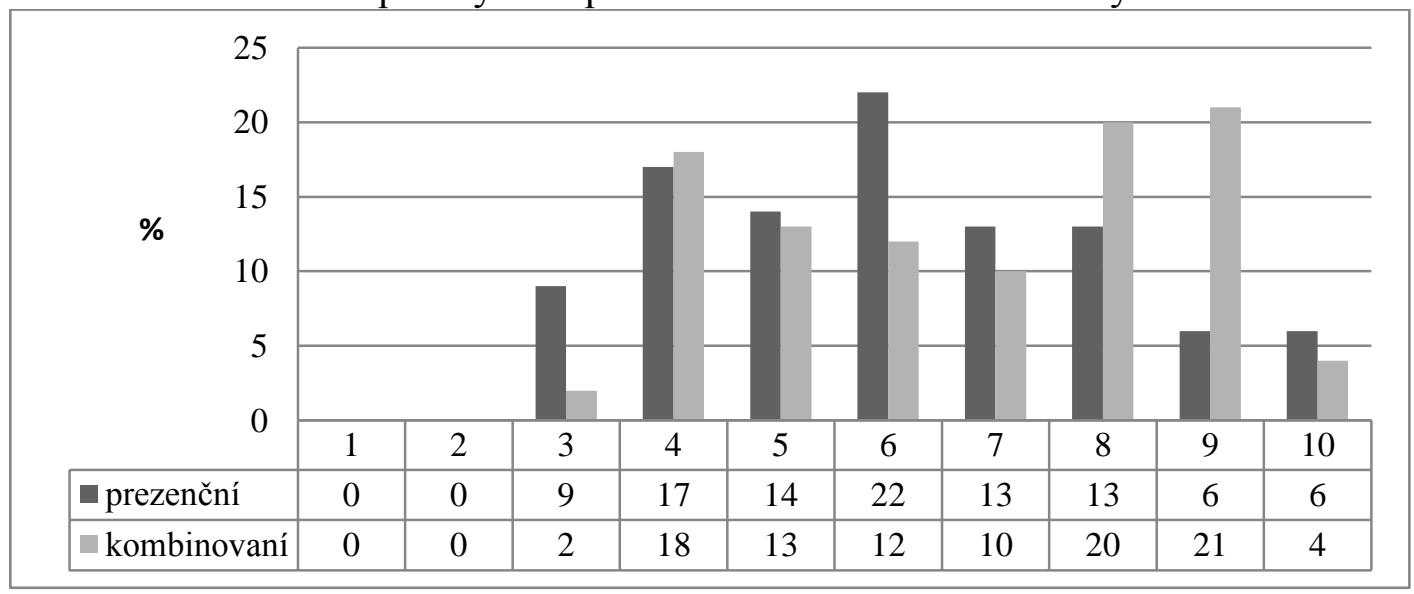

Zdroj: vlastní zpracování

Z výše uvedeného grafu je zřejmé, že modus pro prezenční studenty se zvýšil na 6 a pro kombinované dokonce na 9. Také vážený aritmetický průměr (viz tabulka 1) prezentuje lepší výsledky kombinovaných studentů, a to 7 správných odpovědí (u prezenčních studentů to bylo pouze 6 správných odpovědí). 
Tabulka 1: Vážený aritmetický průměr a variabilita znalostí studentů

\begin{tabular}{|l|r|r|r|r|}
\hline & prezenční 1. fáze & prezenční 2. fáze & kombinovaní 1. fáze & kombinovaní 2. fáze \\
\hline Vážený aritmetický průměr & 5,49 & 6,04 & 6,33 & 6,74 \\
\hline Rozptyl s & 0,7776 & 0,9336 & 1,1682 & 1,1316 \\
\hline
\end{tabular}

Zdroj: vlastní zpracování

Na základě výsledků v tabulce 1 je možno konstatovat, že výsledky prezenčních studentů v první i druhé fázi vykazují nižší míru variability než u studentů kombinovaných. U prezenčních studentů se ve druhé fázi výzkumu zvýšil vážený aritmetický průměr, ale současně také vzrostla variabilita, to znamená, že se zvětšil rozdíl v úrovni znalostí studentů. Také u kombinovaných studentů se zvýšil vážený aritmetický průměr a přitom míra variability se mírně snížila.

\subsection{Ověření hypotéz}

Hypotézy byly stanoveny s cílem ověřit, zda existuje významný rozdíl v úrovni daňových znalostí mezi prezenčními a kombinovanými studenty. Byly stanoveny nulové hypotézy samostatně pro prezenční a kombinované studenty, které byly ověrovány pomocí Chi-kvadrát testu.

\section{H10: Znalosti studentů v prezenční formě studia nezávisí na absolvování předmětů.}

Tabulka 2: Ověření hypotézy $\mathrm{H} 1_{0}$

\begin{tabular}{|l|r|}
\hline CHI-SQUARE & 10,79597299 \\
\hline alfa & 0,05 \\
\hline df & 3 \\
\hline CHINV & 7,814727764 \\
\hline CHIDIST & 0,012881868 \\
\hline
\end{tabular}

Zdroj: vlastní zpracování

Na základě výsledků testu, které jsou ve výše uvedené tabulce, byla nulová hypotéza zamítnuta a můžeme učinit závěr, že znalosti studentů v prezenční formě studia závisí na absolvování předmětů.

\section{Znalosti studentů v kombinované formě studia}

\section{H2 : Znalosti studentů v kombinované formě studia nezávisí na absolvování předmětů.}

Tabulka 3: Ověření hypotézy $\mathrm{H} 2_{0}$

\begin{tabular}{|l|r|}
\hline CHI-SQUARE & 5,091068969 \\
\hline alfa & 0,05 \\
\hline df & 3 \\
\hline CHINV & 7,814727764 \\
\hline CHIDIST & 0,165248785 \\
\hline
\end{tabular}

Zdroj: vlastní zpracování

Na základě výsledků testu, které jsou prezentovány v tabulce 3, nulovou hypotézu není možno zamítnout. Znalosti studentů v kombinované formě studia nezávisí na absolvování předmětů.

\section{Diskuze}

Finanční gramotnost každého občana by měla zahrnovat i znalost daňové problematiky. Daně jsou oblastí, se kterou se denně setkává každý občan, at' se jedná o daně neprímé, které jsou součástí cen, tak i o daně prrímé, které se týkají občanů v zaměstnaneckém poměru 
i podnikatelů. Finanční gramotnost je v současné době vyučována také na základních i středních školách a proto bylo v první části výzkumu zjišt’ováno, s jakými znalostmi v oblasti základní daňové problematiky přicházejí studenti na vysokou školu.

Bylo zjištěno, že modus u prezenčních studentů při nástupu na vysokou školu byl sice vyšší než u studentů kombinované formě, ale na druhou stranu vážený aritmetický průměr ukázal lepší výsledky kombinovaných studentů. To bylo dáno zejména velkými rozdíly ve znalostech kombinovaných studentů, kdy více než 8 správných odpovědí mělo $38 \%$ respondentů. Zde se odráží zejména skutečnost, že studenti, kteří pracují nebo pracovali v ekonomickém oboru, vykazují lepší výsledky než ostatní respondenti. Naproti tomu většina studentů v prezenční formě studia vykazovala znalosti průměrné (4 až 7 správných odpovědí mělo $75 \%$ respondentů). Tito studenti také nejčastěji uvádějí, že nepracují (a to $93 \%$ respondentů) a v ekonomické oblasti pracovalo nebo pracuje pouze $3 \%$ dotázaných.

Ačkoliv se úroveň znalostí studentů po absolvování předmětů s daňovou problematikou zvýšila u studentů v prezenční i kombinované formě studia, na základě Chi-kvadrát testu byla potvrzena závislost pouze u studentů v prezenční formě. Zde se projevil rozdíl mezi oběma formami studia, kdy studenti prezenčního studia mohou znalosti získané v rámci přednášek prohlubovat navíc v seminářích, včetně průběžných konzultací s vyučujícími.

Modus u studenti̊ v kombinované formě se zvýšil dokonce až na 9, ale vážený aritmetický průměr se zvýšil pouze na 7 . I v druhé fázi výzkumu po absolvování předmětů dosahovali studenti v kombinované formě průměrně lepších výsledků než studenti prezenční. Co se týká variability výsledků, vykazují prezenční studenti v obou fázích výzkumu nižší hodnoty rozptylu ve srovnání se studenty kombinovanými. To dokazuje vyšší vyrovnanost znalostí prezenčních studentů a na druhou stranu heterogenitu znalostí studentů kombinovaných.

Na základě realizovaného výzkumu bylo zjištěno, že studenti, kteří se hlásí do kombinované formy studia, mají lepší znalosti daňové problematiky. Rozdíly ve znalostech mezi studenty v prezenční a kombinované formě studia jsou ovlivněny zejména skutečností, že na rozdíl od prezenčních studentů, většina kombinovaných studentů pracuje a s daněmi se setkávají $\mathrm{v}$ rámci své profese, ale i v běžném životě.

\section{Závěr}

Finanční a gramotnost jako součást ekonomické gramotnosti tvoří jednu ze složek tzv. klíčových kompetencí, tedy znalostí, dovedností a hodnotových postojů, které by měl občan mít, aby se dokázal uplatnit v současné společnosti. Rozvoj těchto kompetencí je současně prostředkem $\mathrm{k}$ vytváření a posilování politického, právního a ekonomického myšlení občanů. Nedílnou součástí finanční gramotnosti jsou také nezbytné makroekonomické aspekty a oblast daňová, a to zejména vzhledem $\mathrm{k}$ tomu, že se významně podílí na finančních zdrojích jednotlivců i domácností, a má tedy významný vliv na peněžní toky v soukromých financích. Každý jednotlivec by měl mít základní povědomí o systému a formě zdaňování a přehled o tom, jaké daně a v jaké výši běžně platí. Základní povědomí o daňovém systému a roli daní v rámci občanské společnosti je nutné chápat jako prvek k zajištění odpovědného chování občanů vůči rodině a státu.

Daňová legislativa významnou měrou ovlivňuje podnikatelské i společenské prostředí v České republice. Proto je záměrem Obchodně podnikatelské fakulty v Karviné poskytnout studentům $\mathrm{v}$ rámci výuky klíčové informace $\mathrm{z}$ oblasti daní a daňové politiky státu. Důraz je kladen na teoretické znalosti a na praktickou aplikaci získaných vědomostí, včetně 
prohloubení znalostí v oblasti prímých i nepř́mých daní. Tyto znalosti a dovednosti nejsou stěžejní pouze pro budoucí kariéru absolventů OPF v Karviné, ale také pro jejich osobní rozhodování, jelikož daňová gramotnost by měla zahrnovat orientaci v daňovém systému i významných formách daňové optimalizace jako je uplatnění slev na dani, daňových odpočtů, a daňového zvýhodnění.

Jednou ze základních specifik výuky této oblasti jsou zejména časté změny daňové legislativy a př́stupu státu $\mathrm{k}$ daňové politice. Problémem daňového systému České republiky je jeho složitost a nepřehlednost což umožňuje i nenápadné zvyšování některých daní. Dosažení a udržení základní daňové gramotnosti navíc komplikují velmi časté změny daňové legislativy.

Na základě realizovaného výzkumu bylo zjištěno a statisticky ověřeno, že ačkoliv se úroveň znalostí studentů po absolvování předmětů s daňovou problematikou zvýšila u studenti̊ v prezenční i kombinované formě studia, na základě Chi-kvadrát testu byla potvrzena závislost pouze u studentů v prezenční formě, jelikož studenti mohou znalosti získané v rámci přednášek prohlubovat navíc v seminářích, včetně průběžných konzultací s vyučujícími.

Studenti, kteří se hlásí do kombinované formy studia, mají lepší znalosti daňové problematiky. Rozdíly ve znalostech mezi studenty v prezenční a kombinované formě studia mohou být ovlivněny zejména skutečností, že na rozdíl od prezenčních studentů, většina studentů kombinované formy studia již pracuje a s daněmi se setkává nejen v běžném životě, ale i v rámci své profese.

\section{Poděkování}

„Tento článek vznikl za podpory Ministerstva školství, mládeže a tělovýchovy ČR v rámci Institucionální podpory na dlouhodobý koncepční rozvoj výzkumné organizace v roce 2015.“

\section{Literatura}

[1] BLECHOVÁ, B., 2012. Progresivní nebo „rovná“ daň - ekonomické a politické dilema. Politická ekonomie, 60(5), 649-668. Praha: VŠE v Praze. ISSN 0032-3233.

[2] BLECHOVÁ, B. a Š. SOBOTOVIČOVÁ, 2013. Daňová vzdělanost jako součást finanční gramotnosti. Trendy ekonomiky a managementu, VII(7/14), 17-24. Brno: VUT v Brně. ISSN 1802-8527.

[3] BOCCANFUSO, D., A. LAROUCHE and M. TRANDAFIR, 2015. Quality of Higher Education and the Labor Market in Developing Countries: Evidence from an Education reform in Senegal. World Development, 74, 412-424. ISSN 0305-750X. DOI: 10.1016/j.worlddev.2015.05.007

[4] Commission decision 2008/365/EC. Official Journal of the European Union [online]. 9. 5. 2008 [vid. 10. srpna 2015]. Dostupné z: eur-lex.europa.eu/ LexUriServ/LexUriServ.do?uri=OJ:L:2008:125:0036:0038:EN:PDF

[5] CSONGOR, S., 2011. Financial Literacy and Self-care in Hungary. Agricultural Management, 13(1), 311-318. ISSN 1453-1410.

[6] DISNEY, R. and J. GATHERGOOD, 2013. Financial literacy and consumer credit portfolios. Journal of Banking \& Finance, 37(7), 2246-2254. ISSN 1916-971X.

[7] ERIKSEN, K. and L. FALLAN, 1996. Tax knowledge and attitudes towards taxation; A report on a quasi-experiment. Journal of economic psychology, 17(3), 387-402. ISSN $0167-4870$. 
[8] GILLEN, M. and D. N. LOEFFLER, 2012. Financial literacy and social work students: Knowledge is power. Journal of Financial Therapy, 3(2), 28-38. ISSN 1944-9771.

[9] HADI, R., U. WAHYUDIN, J. S. ARDIWINATA and W. J. ABDU, 2015. Education and microfinance: an alternative approach to the empowerment of the poor people in Indonesia. SpringerPlus [online]. 4(1) [vid. 2. zárí 2015]. Dostupné z: Www.springerplus.com/content/4/1/244

[10] CHARDON, T., 2014. Taxation and superannuation literacy in Australia: what do people know (or think they know)? JASSA, 1, 42-48. ISSN 0313-5934.

[11] JANOUŠKOVÁ, J., 2011. Daně a daňová politika: osobní důchodová dan̆. Karviná: SU OPF. ISBN 978-80-7248-698-4.

[12] JANOUŠKOVÁ, J. a Š. SOBOTOVIČOVÁ, 2013. Daňová vzdělanost v kontextu širších souvislostí edukačního procesu. In: J. VANĚK, ed. Rozvoj kličových kompetencí pracovniků vysokých škol. Karviná: SU OPF, s. 116-123. ISBN 978-80-7248-922-0.

[13] KAMALUDDIN, A. and N. MADI, 2005. Tax literacy and Tax awareness of Salaried Individuals in Sabah and Sarawak. Journal of Financial Reporting and Accounting, 3(1), 71-89. ISSN 1985-2517.

[14] KOLLÁRIKOVÁ, T., 2014. Education as an important factor of the situation of young people in the labor market. Acta academcia karviniensia, XIV(3), 88-98. Karviná: SU OPF. ISSN 1212-415X.

[15] KUCHARČÍKOVÁ, A., 2014. Investment in the human capital as the source of economic growth. Periodica Polytechnica Social and Management Sciences, 22(1), 2935. ISSN 1587-3803.

[16] MADI, N., A. KAMALUDDIN, T. JANGGU, M. B. A. IBRAHIM, A. B. A. SAMAH and K. JUSOFF, 2010. Tax literacy among employees: Sabah and Sarawak's perspective. International Journal of Economics and Finance, 2(1), 218-223. ISSN 1916-971X.

[17] PASEKOVÁ, M., H. ŘEDINOVÁ, V. OPREAN, K. KALLASTE, L. HOMOLKA, B. BLECHOVÁ and Š. SOBOTOVIČOVÁ, 2013. The level of financial literacy among the high school students in the chosen regions of the Czech Republic. International Journal of Mathematical Models and Methods in Applied Sciences, 7(4), 462-469. ISSN 19980140 .

[18] TOKARČÍKOVÁ, E., A. KUCHARČÍKOVÁ and M. ĎURIŠOVÁ, 2015. Education of Students of the Study Program Informatics in the Field of Corporate Social Responsibility. Periodica Polytechnica Social and Management Sciences, 23(2), 106112. ISSN 1587-3803.

[19] VYBÍHAL, V. a kol., 2011. Slabikář Finanční gramotnosti. 2. aktualizované vydání. Praha: COFET, a.s. ISBN 978-80-9043-96-1-0

[20] YILMAZ, H., 2011. Improving Financial Literacy: The U.S. Experience. International Journal of Business and Social Science, 2(11), 65-72. ISSN 2219-1933. 